\title{
Kreativitas Guru dalam Mengatasi Kesulitan Belajar Siswa pada Mata Pelajaran IPS di Smp Negeri 34 Semarang Tahun Pelajaran 2017/2018
}

\section{Frishana Selaksa Ulul Azmi, Arif Purnomo, Ferani Mulianingsih}

Social Science Education Department, Faculty of Social Science, Universitas Negeri Semarang, Indonesia

\begin{abstract}
Info Artikel
Sejarah Artikel:

Disubmit:

Direvisi:

Diterima:

Keywords:

teachers' ceativity, learning dfficulties, learning of social studies

Abstrak

Guru merupakan peranan penting dalam proses pembelajaran. Selain sebagai pengajar, guru harus berperan sebagai fasilitator dan motivator bagi siswa. Kreativitas guru sangat penting sebagai penunjang dalam pembelajaran untuk mencapai tujuan belajar siswa. Upaya yang dilakukan guru dengan memunculkan berbagai ide-ide baru, caracara baru yang dapat menjadikan siswa aktif, serta dapat meminimalisir penyebab kesulitan belajar siswa pada mata pelajaran IPS. Metode penelitian adalah penelitian kualitatif, dengan lokasi penelitian di SMP Negeri 34 Semarang. Hasil penelitian kreativitas guru dalam mengatasi kesulitan belajar siswa pada mata pelajaran IPS terdapat dua faktor yaitu faktor internal dan faktor eksternal, guru berupaya dalam mengatasi kesulitan belajar siswa, adapun upaya yang telah dilakukan oleh guru, terdapat kendala yang dihadapi guru dalam mengatasi kesulitan belajar siswa.
\end{abstract}

\section{Abstract}

Teacher is an important part in the learning process. Besides teaching, the teacher should act as facilitator and motivator for students. Teachers' Creativity is very important as a support in learning to achieve the learning objectives of the students. Efforts which are done by the teachers are showing up new various ideas, new ways that can make students active, and be able to minimize the causes of learning difficulties of students in Social Science or Ilmu Pengetahuan Sosial (IPS) subject. The research method is qualitative research, with the location of the research is in SMP Negeri 34 Semarang. The research result of teacher creativity in overcoming learning difficulties of students in Social Science subject, there were two factors, namely the internal factors and external factors, the teachers were trying in overcoming learning difficulties of students, as for the efforts that have been done by the teachers, there were obstacles that must be faced by the teachers in overcoming learning difficulties of students.

\footnotetext{
Alamat korespondensi:

Gedung C1 Lantai 1 FIS Unnes

Kampus Sekaran, Gunungpati, Semarang, 50229

E-mail: jurnalsosioliumpips@mail.unnes.ac.id
}

E-ISSN 2685-4929 


\section{PENDAHULUAN}

Dalam proses pendidikan di sekolah, kegiatan belajar merupakan faktor paling penting, dimana belajar merupakan suatu proses usaha yang dilakukan seseorang untuk memperoleh hasil yang diinginkan. Belajar bukan hanya mengingat, akan tetapi lebih luas dari pada itu, yaitu mengalami (Hamalik, 2005: 36).

Salah satu komponen penting dalam upaya meningkatkan mutu pendidikan nasional adalah adanya guru yang berkualitas, profesional dan berpengetahuan. Guru, tidak hanya sebagai pengajar, namun guru juga mendidik, membimbing, mengarahkan, melatih, menilai, dan mengevaluasi peserta didik. Dalam menjalankan tugasnya sebagai agen pembelajaran. Guru yang profesional adalah guru yang menguasai materi pembelajaran, menguasai kelas dan mengendalikan perilaku anak didik, menjadi teladan, membangun kebersamaan, menghidupkan suasana belajar dan menjadi manusia pembelajar (Wahab, 2015: 77-78). Begitu pentingnya peranan guru dalam keberhasilan peserta didik maka hendaknya guru mampu beradaptasi dengan berbagai perkembangan yang ada dan meningkatkan kompetensinya sebab guru pada saat ini bukan saja sebagai pengajar tetapi juga sebagai pengelola proses belajar mengajar. Sebagai orang yang mengelola proses belajar mengajar tentunya harus mampu meningkatkan kemampuan dalam membuat perencanaan pelajaran, pelaksanaan dan pengelolaan pengajaran yang efektif, penilaian hasil belajar yang objektif, sekaligus memberikan motivasi pada peserta didik dan juga membimbing peserta didik terutama ketika peserta didik sedang mengalami kesulitan belajar (Saondi dan Aris Suherman, 2010: 19).

Kreativitas guru dalam proses pembelajaran mempunyai peranan penting dalam peningkatan mutu dan hasil belajar siswa. Kreativitas merupakan kemampuan yang dimiliki seseorang untuk menemukan dan menciptakan sesuatu hal baru, cara-cara baru, model baru yang berguna bagi dirinya dan bagi masyarakat (Sukmadinata, 2009:104). Bila hal ini dikaitkan dengan kreativitas guru, guru dapat menciptakan suatu strategi mengajar yang baru dengan berbagai cara dan model pembelajaran yang dapat mengurangi penyebab kesulitan belajar siswa dan dapat meningkatkan hasil belajar siswa.

Kreativitas guru dalam proses belajar mengajar ternyata masih kurang, hal ini terjadi berdasarkan pengamatan yang dilakukan peneliti pada saat observasi awal pada tanggal 06 Februari 2018-13 Februari 2018 di SMP Negeri 34 Semarang terletak di Jl. Tlogomulyo Pedurungan, Kota Semarang. Dalam kegiatan belajar tidak senantiasa berhasil pasti ada rintangan dan hambatannya. Seperti yang terjadi di SMP Negeri 34 Semarang siswa mengalami gejala kesulitan belajar pada mata pelajaran IPS. Dilihat dari nilai ulangan siswa yang masih rendah di bawah Kriteria Ketuntasan Minimal (KKM), dalam proses pembelajaran guru masih sering menggunakan metode ceramah, metode dan model pembelajaran yang diberikan oleh guru kurang menarik dan menyenangkan, kurangnya minat belajar siswa terhadap pembelajaran IPS, serta rendahnya motivasi belajar siswa. Terkait sarana dan prasarana dalam pembelajaran yaitu buku yang ada di perpustakaan kurang lengkap hanya terdapat buku paket, dan buku referensi pendukung IPS lainnya masih kurang, selain itu hanya ada globe saja, tidak ada atlas sebagai penunjang siswa dalam media pembelajaran, peta Indonesia diletakkan di dinding kelas, beberapa kelas terdapat LCD dan proyektor, namun tidak dapat digunakan juga berpengaruh bagi proses pembelajaran di kelas dan tidak ada fasilitas laboratorium IPS.

\section{METODE}

Metode penelitian adalah penelitian kualitatif, dengan lokasi penelitian di SMP Negeri 34 Semarang. Sumber data primer dalam penelitian adalah guru IPS, guru BK, dan peserta didik. Sumber data sekunder diambil dari silabus, RPP, soal remidi dan pengayaan, nilai kognitif, nilai afektif, pekerjaan orang tua 
dan penghasilan. Teknik pengumpulan data yang digunakan adalah wawancara, observasi, dan dokumentasi. Uji keabsahan data menggunakan triangulasi teknik dan triangulasi sumber untuk menguji kebenaran data yang diperoleh. Teknik analisis data menggunakan analisis data model interaktif yang meliputi pengumpulan data, reduksi data, penyajian data, dan penarikan kesimpulan atau verifikasi.

\section{HASIL DAN PEMBAHASAN}

\section{Faktor Penyebab Kesulitan Belajar Siswa di SMP Negeri 34 Semarang}

Terdapat dua faktor yang mempengaruhi penyebab kesulitan belajar siswa yaitu faktor internal (dari dalam diri) dan faktor eksternal (dari luar diri). Dalam hasil penelitian di SMP Negeri 34 Semarang terdapat faktor internal penyebab kesulitan belajar yaitu: 1) sikap bosan siswa. Salah satu faktor penyebab kesulitan belajar oleh Dimyati dan Mudjiono (2006: 239) yaitu Sikap terhadap belajar. Sikap merupakan kemapuan memberikan penilaian tentang sesuatu, yang membawa diri sesuai dengan penilaian. Adanya penilaian tentang sesuatu, mengakibatkan terjadinya sikap menerima, menolak, atau mengabaikan. Siswa memperoleh kesempatan belajar. Meskipun demikian, siswa dapat menerima, menolak, atau mengabaikan kesempatan belajar tersebut. Hal tersebut sejalan dengan pengamatan pada penelitian yang dilakukan di SMP Negeri 34 Semarang menandakan adanya sikap bosan siswa saat mengikuti pembelajaran IPS dikarenakan rendahnya minat belajar siswa terhadap mata pelajaran IPS, materi pada mata pelajaran IPS terlalu banyak, susah dipahami dan rumit karena mempelajari materi geografi, ekonomi, sejarah.

Selanjutnya, 2) tidak fokus belajar. Teori dikemukakan oleh Dimyati dan Mudjiono (2006: 239-240) Faktor internal yang menyebabkan kesulitan belajar siswa yaitu konsentrasi belajar. Konsentrasi belajar merupakan kemampuan memusatkan perhatian pada pelajaran. Pemusatan perhatian tersebut tertuju pada isi bahan belajar maupun proses memperolehnya. Untuk memperkuat perhatian pada pelajaran, guru perlu menggunakan bermacam-macam strategi belajar-mengajar, dan memperhitungkan waktu belajar serta selingan istirahat. Sejalan dengan hasil penelitian di SMP Negeri 34 Semarang, siswa yang tidak fokus saat pembelajaran disebabkan karena berbicara sendiri dengan temannya, keadaan kelas yang ramai, mengantuk, melamun, dan dari dalam diri siswa itu sendiri yang menyebabkan tidak dapat fokus dalam menerima pembelajaran. Sehingga mengganggu konsetrasi belajar siswa tersebut dalam proses pembelajaran IPS.

Faktor berikutnya 3) tidak gemar membaca dan sulit untuk menghafal. Menurut Rahim dalam (Sofyan, 2015:18) menyatakan minat baca adalah keinginan yang kuat disertai dengan usaha-usaha seseorang untuk membaca. Orang yang mempunyai minat membaca yang kuat akan diwujudkannya dalam kesediaannya untuk mendapat bahan bacaan dan kemudian membacanya atas kesadarannya sendiri atau dorongan dari luar. Sejalan dengan hasil penelitian faktor internal penyebab kesulitan belajar siswa pada mata pelajaran IPS di SMP Negeri 34 Semarang yaitu siswa tidak gemar membaca dan sulit untuk menghafal, sedangkan berbanding terbaik dengan materi IPS yang materinya banyak bacaan, peristiwa masa lampau, dan berkutik dengan kata-kata tidak angka. Pembelajaran IPS pada dasarnya materinya banyak dan menuntut siswa untuk banyak membaca dan menghafal. Jika siswa tidak gemar membaca dan sulit untuk menghafal maka dapat menyebabkan siswa mengalami kesulitan belajar pada mata pelajaran IPS.

Kemudian, 4) kebiasaan belajar siswa. Menurut Aziz dalam (Megayanti, 2016: 2.849) malas berbeda dengan lamban. Anak lamban masih memiliki kemauan untuk melakukan sesuatu walaupun lama dalam prosesnya, sedangkan anak malas cenderung menunjukkan tidak adanya kemauan. Rasa malas dalam belajar dapat berupa tidak mengerjakan pekerjaan rumah (PR), malas belajar pelajaran sekolah, menunda-nunda pekerjaan, bahkan 
tidak mengikuti pelajaran di kelas. Hasil penelitian kebiasaan belajar siswa SMP Negeri 34 Semarang masih kurang baik dan belum maksimal, belajar jika ada niat, belajar jika ada $\mathrm{PR}$, ulangan, dan belajar dibarengi dengan main hp dan nonton tv. Sehingga dapat mempengaruhi hasil belajar siswa serta nilai yang di dapat juga masih kurang dan di bawah KKM.

Terakhir, 5) rendahnya motivasi belajar siswa. Teori tentang faktor internal penyebab kesulitan belajar oleh Dimyati dan Mudjiono (2006: 239) yaitu motivasi belajar. Motivasi belajar merupakan kekuatan mental yang mendorong terjadinya proses belajar. Motivasi belajar pada diri siswa dapat menjadi lemah. Lemahnya motivasi, atau tiadanya motivasi belajar akan melemahkan kegiatan belajar. $\mathrm{Hal}$ tersebut sejalan dengan hasil penelitian yang dilakukan di SMP Negeri 34 Semarang. Berdasarkan hasil wawancara yang dilakukan oleh peneliti penyebabnya karena tidak ada semangat dan motivasi belajar dari diri sendiri, tidak ada kemauan untuk bertanya kepada guru apabila tidak bisa mengerjakan tugas atau tidak paham pada materi tertentu, banyaknya bacaan dan materi IPS menjadikan siswa malas untuk belajar.

Faktor ekstern penyebab kesulitan belajar siswa di SMP Negeri 34 Semarang sebagai berikut: Guru. Faktor eksternal penyebab kesulitan belajar oleh Dimyati dan Mudjiono (2006: 248-249) guru adalah pengajar yang mendidik. Ia tidak hanya mengajar bidang studi yang sesuai dengan keahliannya, tetapi juga menjadi pendidik generasi muda bangsanya. Sebagai pendidik, ia memusatkan perhatian pada kepribadian siswa, khususnya berkenaan dengan kebangkitan belajar. Sebagai guru, ia bertugas mengelola kegiatan belajar siswa di sekolah. Guru mempunyai kewajiban dalam mendidik siswa menjadi siswa yang cerdas dan berguna. Dapat disimpulkan bahwa metode yang guru terapkan masih sering menggunakan metode ceramah, bercerita, dan diskusi. Media yang digunakan yaitu LCD, dan salah satu guru menggunakan media mind mapping untuk menunjang proses belajar mengajar. Jika seringnya guru menerapkan metode ceramah dapat menyebabkan siswa merasa kurang minat dan kurang tertarik dalam pembelajaran IPS dikarenakan siswa bosan jika hanya mendengarkan guru yang hanya menggunakan metode ceramah. Siswa juga merasa bosan saat pembelajaran berlangsung. Serta menurut pendapat salah satu siswa, pada saat pembelajaran IPS, ketika guru menyampaikan materi pelajaran kurang jelas dan sulit untuk dipahami.

Sarana dan prasarana. Teori yang dikemukakan oleh Dimyati dan Mudjiono (2006: 249-250) faktor eksternal penyebab kesulitan belajar yaitu sarana dan prasarana. Prasarana pembelajaran meliputi gedung sekolah, ruang belajar, lapangan olahraga, ruang ibadah, ruang kesenian, dan peralatan olahraga. Sarana pembelajaran meliputi buku pelajaran, buku bacaan, alat dan fasilitas laboratorium sekolah, dan berbagai media pengajaran yang lain. Lengkapnya prasarana dan sarana pembelajaran merupakan kondisi pembelajaran yang baik. Apabila sarana pembelajaran disekolah kurang lengkap maka dapat mempengaruhi siswa dalam proses pembelajaran sehingga siswa sulit untuk mengembangkan kemampuannya. Ada beberapa sarana dan prasarana yang kurang lengkap di SMP Negeri 34 Semarang. Seperti pengamatan yang dilakukan peneliti dengan pernyataan guru mata pelajaran IPS. Buku utama yaitu paket sudah lengkap namun buku penunjang referensi IPS masih kurang lengkap, terdapat lima kelas sudah ada LCD dan proyektornya, namun masih belum dapat digunakan kelas VII F, VIII B, VIII F, VIII G, dan IX C, serta belum adanya laboratorium IPS.

Orang tua. Menurut Ahmadi dan Widodo Supriyono (2004:87) belajar memerlukan bimbingan dari orang tua agar sikap dewasa dan tanggung jawab belajar, tumbuh pada diri anak. Orang tua yang sibuk bekerja, terlalu banyak anak yang diawasi, sibuk organisasi, berarti anak tidak mendapatkan pengawasan/bimbingan dari orang tua, hingga kemungkinan akan banyak mengalami kesulitan belajar. Hasil penelitian di SMP Negeri 34 
Semarang bahwa penyebab kesulitan belajar siswa yaitu perekonomian orang tua masih rendah. Sehingga orang tua sibuk bekerja mencari uang untuk menyekolahkan anaknya sehingga Orang tua siswa kurang memperhatikan belajar siswa pada saat di rumah, siswa merasa orang tua jarang menyuruh untuk belajar, dan ketika belajar orang tua pun masih menonton tv sehingga anak tidak dapat maksimal dalam belajarnya.

Lingkungan sosial. Dimyati dan Mudjiono (2006:252-253) yaitu lingkungan sosial. Tiap siswa berada dalam lingkungan sosial siswa di sekolah. Ia memiliki kedudukan dan peranan yang diakui oleh sesama. Jika seorang siswa terterima, maka ia dengan mudah menyesuaikan diri dan segera dapat belajar. Sejalan dengan hasil yang dilakukan di SMP Negeri 34 Semaran bahwa lingkungan sosial di sekolah dapat mempengaruhi dampak yang buruk bagi siswa. Dalam milih teman itu perlu dan tidak hanya ikut-ikut apa yang dilakukan teman tidak semuanya baik. Hal tersebut dapat menjadikan siswa mengalami kesulitan belajar dikarenakan tidak mengerjakan tugas sehingga nilainya menurun, berbuat yang tidak baik ijin ke kamar mandi namun, tujuannya ke kantin padahal masih waktu jam pelajaran.

\section{Upaya Guru dalam Mengatasi Kesulitan Belajar Siswa}

Upaya yang dilakukan guru dalam mengatasi kesulitan belajar siswa sebagai berikut.

Rencana Pelaksanaan Pembelajaran (RPP). Menurut Mulyasa (2009: 81) Guru perlu membuat suatu perencanaan yang baik untuk memberikan penjelasan. Sedikitnya ada dua hal yang perlu diperhatikan dalam perencanaan penjelasan, yaitu isi pesan yang akan disampaikan dan peserta didik. Yang berhubungan dengan isi pesan (materi standar): 1) Tetukan garis besar materi yang akan dijelaskan, 2) Susunlah garis besar materi tersebut secara sistematis dengan bahasa yang mudah dipahami peserta didik, 3) Siapkan alat peraga untuk memberikan contoh (ilustrasi) yang sesuai dengan garis besar materi yang akan dijelaskan. Hal tersebut sejalan dengan hasil penelitian di SMP Negeri 34 Semarang. Guru IPS sebelum melaksanakan proses pembelajaran merancang pelaksanaan pembelajaran guna mencapai tujuan pembelajaran. Dalam Rencana Pelaksanaan Pembelajaran (RPP) yang disusun oleh tim MGMP yang telah dirubah sedikit demi sedikit oleh Bapak Sarwoto dan Ibu Siti guna mendapatkan proses belajar yang diinginkan, dan mencapai tujuan belajar yang diharapkan. Hal tersebut merupakan kreativitas guru dalam mengembangkan Rencana Pelaksanaan Pembelajaran (RPP) guna mendapatkan hasil yang maksimal.

Pengelolaan Kelas. Fungsi guru oleh Gagne dalam (Syah, 2008:251) Guru sebagai manager of instruction, artinya sebagai pengelola pengajaran. Fungsi ini menghendaki kemampuan guru dalam mengelola (menyelenggarakan dan mengendalikan) seluruh tahapan proses belajar-mengajar. Kegiatan-kegiatan pengelolaan proses belajar mengajar, yang terpenting ialah menciptakan kondisi dan situasi sebaik-baiknya, sehingga memungkinkan para siswa belajar secara berdayaguna dan berhasil guna. Setiap guru memiliki cara masing-masing untuk mengondisikan kelas, hal tersebut sejalan dengan hasil pengamatan dan wawancara dengan guru mata pelajaran IPS yaitu yang biasa guru lakukan mengondisikan siswanya terlebih dahulu, menyuruh siswa untuk menyiapkan buku pelajaran IPS dan alat tulis, lalu ketika keadaan kelas tidak kondusif di tengah-tengah pembelajaran guru pastinya pertama di nasehati, diingatkan, di tegur dengan tegas. Jika hal tersebut tidak berhasil, maka guru ada yang menyuruh anak keluar kelas, dan ada pula yang diberi poin.

Menggunakan media dan metode dalam pembelajaran. Menurut Mulyasa (2009: 177) sumber belajar dapat dirumuskan sebagai segala sesuatu yang dapat memberikan kemudahan belajar, sehingga diperoleh sejumlah informasi, pengetahuan, pengalaman, dan keterampilan yang diperlukan. Dalam hal ini nampak adanya beraneka ragam sumber belajar yang masingmasing memiliki kegunaan tertentu yang mungkin sama atau bahkan berbeda dengan 
sumber belajar lain. Sejalan dengan hasil pengamatan yang dilakukan oleh peneliti, upaya guru dalam menggunakan metode dan media sudah sesuai dan layak diterapkan dalam pembelajaran IPS, siswa terlihat aktif ketika guru menggunakan metode dan media pembelajaran. Selain media LCD, Bapak Sarwoto menggunakan media mind mapping di awal bab baru dalam pembelajaran Metode yang digunakan guru yaitu metode diskusi kelompok yang terdiri dari 3-5 anggota tiap kelompoknya. Namun, guru belum maksimal dalam menggunakan media pembelajaran di beberapa kelas, dikarenakan terdapat lima ruang kelas yang LCDnya tidak dapat digunakan.

Memberikan Penguatan berupa semangat dan motivasi belajar siswa. Menurut Callahan and Clark dalam (Mulyasa, 2009: 174) mengemukakan bahwa motivasi adalah tenaga pendorong atau penarik yang menyebabkan adanya tingkah laku ke arah suatu tujuan tertentu. Dengan motivasi akan tumbuh dorongan untuk melakukan sesuatu dalam kaitannya dengan pencapaian tujuan. upaya yang dilakukan ketiga guru IPS agar meningkatkan semangat dan motivasi belajar siswa. Selalu memberikan semangat dan motivasi belajar baik di awal, di pertengahan pembelajaran atau di akhir pembelajaran. Pada saat pembelajaran guru memberikan pujian berupa "bagus", "pintar sekali", "sip". Serta memberikan wejangan-wejangan yang membangun untuk meningkatkan hasil belajar siswa agar siswa giat dalam belajar dan meraih cita-citanya. Guru juga memberi semangat dan motivasi belajar jika siswa akan menghadapi ulangan atau ujian.

Program remidial dan pengayaan. Menurut Ahmad dan Widodo Supriyono (2004: 152-153) Remedial teaching atau pengajaran perbaikan adalah suatu bentuk pengajaran yang bersifat menyembuhkan atau membetulkan, atau dengan singkat pengajaran yang membuat menjadi lebih baik. Teori tersebut dengan hasil penelitian adanya kesesuaian bahwa jawaban ketiga guru IPS semua sama yaitu semua anak yang nilai dibawah KKM di berikan program remidi, sedangkan anak yang nilainya di atas
KKM diberi program pengayaan. Guru mengadakan program tersebut bertujuan agar menambah nilai yang kurang, selain itu guru juga bisa melihat sejauh mana kemampuan siswa dalam menyerap materi yang ada diterangkan guru sebagai bahan evaluasi guru dalam mengajar. Program remidial dan pengayaan ini di terapkan di setiap kelas, karena program ini dianggap sangat penting dalam memperbaiki nilai yang diperoleh siswa dalam mata pelajaran IPS. Upaya tersebut dilakukan setiap kali guru mengadakan ulangan harian, dan ujian.

Kendala Guru dalam Mengatasi Kesulitan Belajar Siswa

Kendala-kendala yang dihadapi guru IPS dalam mengatasi kesulitan belajar siswa sebagai berikut.

Kendala Sarana dan Prasarana dalam Pembelajaran. Apabila sarana pembelajaran disekolah kurang lengkap maka dapat mempengaruhi siswa dalam proses pembelajaran sehingga siswa sulit untuk mengembangkan kemampuannya. Sedangkan berdasarkan hasil penelitian yang dilakukan oleh peneliti menemukan kendala berupa sarana dan prasarana yaitu terdapat di empat kelas adanya LCD, namun tidak dapat digunakan di kelas yang diampu oleh Ibu Siti. Hal tersebut dapat mempengaruhi proses pembelajaran yang sudah di rancang oleh Ibu Siti, dan dapat menjadi kendala bagi siswa semakin merasa bosan jika pembelajaran selalu menggunakan metode ceramah dan diskusi tanpa adanya media pembelajaran. Antara teori dengan hasil penelitian tampaknya ada kesesuaian karena LCD merupakan sarana untuk menunjang proses pembelajaran. Apabila tidak dapat digunakan maka dapat menghambat proses pembelajaran tersebut.

Kendala dalam Mengatasi Siswa yang Memiliki Motivasi Rendah. Kendala yang dialami oleh Ibu Sri mengenai kendala dalam mengatasi kesulitan belajar siswa yaitu rendahnya motivasi belajar siswa padahal guru sudah berupaya untuk meningkatkan semangat dan motivasi belajar siswa dengan menyelipkan masukan-masukan yang membangun pada saat 
pembelajaran IPS berlangsung. Berbagai upaya sudah dilakukan Ibu Sri untuk meningkatkan semangat siswa saat mengikuti pembelajaran IPS di kelas.

Mengatasi Siswa yang Sulit Diarahkan dalam Hal Kebaikan pada saat Pembelajaran IPS. Perlu adanya usaha-usaha yang dilakukan oleh guru dalam melakukan bimbingan belajar. Kendala yang dialami oleh salah satu guru IPS yaitu kendala yang dialami Bapak Sarwoto mungkin menjadi kendala juga bagi guru-guru lainnya karena menghadapi siswa itu tidak mudah, siswa memiliki karakter yang berbedabeda antara satu dengan yang lain. Peneliti menyimpulkan bahwa kendala yang dialami Bapak Sarwoto yaitu sulit mengarahkan siswa kearah yang baik pada saat pembelajaran IPS.

\section{SIMPULAN}

Simpulan dari hasil penelitian Kreativitas Guru dalam Mengatasi Kesulitan Belajar Siswa pada Mata Pelajaran IPS di SMP Negeri 34 Semarang Tahun Pelajaran 2017/2018, dapat ditarik kesimpulan bahwa faktor penyebab kesulitan belajar siswa di SMP Negeri 34 Semarang yaitu terdapat dua faktor, faktor internal (dari dalam diri siswa) dan faktor eksternal (dari luar diri siswa). Faktor internal meliputi sikap bosan siswa, tidak fokus belajar, tidak gemar membaca dan sulit untuk menghafal, kebiasaan belajar dan rendahnya motivasi belajar siswa. Sedangkan faktor eksternal meliputi guru, sarana dan prasarana dalam pembelajaran, orang tua, dan lingkungan sosial.

Upaya yang telah dilakukan oleh guru dengan mengembangkan pemikiran-pemikiran kreativitas guru dalam mengatasi kesulitan belajar siswa meliputi Rencana Pelaksanaan Pembelajaran (RPP), pengelolaan kelas, menggunakan media dan metode dalam pembelajaran, memberikan penguatan berupa semangat dan motivasi belajar siswa, dan program remidial dan pengayaan. Kreativitas guru yang dikembangkan dalam berbagai upaya guru tersebut di rasa masih kurang. Hal ini dibuktikan dengan masih ada beberapa guru IPS yang belum mengembangkan ide-ide baru dalam proses pembelajaran IPS.

3. Kendala yang dihadapi guru dalam mengatasi kesulitan belajar siswa meliputi kendala sarana dan prasarana dalam pembelajaran, kendala dalam mengatasi siswa yang memiliki motivasi rendah dalam belajar, dan kendala dalam mengatasi siswa yang sulit diarahkan dalam hal kebaikan pada saat pembelajaran IPS.

\section{DAFTAR PUSTAKA}

Ahmadi, Abu dan Widodo Supriyono. 2004. Psikologi Belajar. Jakarta: Rineka Cipta.

Dimyati dan Mudjiono. 2006. Belajar dan Pembelajaran. Jakarta: Rineka Cipta.

Hamalik, Oemar. 2005. Kurikulum dan Pembelajaran. Jakarta: Bumi Aksara.

Megayanti. 2016. Identifikasi Faktor-faktor Penyebab Siswa Malas Belajar pada Kelas V. Dalam Jurnal Guru Sekolah Dasar. Edisi. 30. Tahun ke5. Hal. 2.848-2.853.

Mulyasa, E. 2009.Menjadi Guru Profesional Menciptakan Pembelajaran Kreatif dan Menyenangkan.Bandung: PT Remaja Rosda karya Offset.

Saondi, Ondi dan Aris Suherman.2010. Etika Profesi Guru. Bandung: PT Refika Aditama.

Sofyan, M. Hamzah. 2015. Meningkatkan Motivasi Membaca. Dalam Jurnal Iqra. Vol. 9. No. 2. Hal. 17-28.

Sukmadinata, Nana Syaodih. 2009. Landasan Psikologi Proses Pendidikan. Bandung: PT Remaja Rosdakarya Offset.

Syah, Muhibbin. 2008. Psikologi Pendidikan Dengan Pendekatan Baru. Bandung: PT Remaja Rosdakarya Offset.

Wahab, Rohmalina. 2015. Psikologi Belajar. Jakarta: Rajawali Pers. 